\title{
Impact of Rural Urban Migration on Economic
}

\section{Sources in Mogadishu - Challenges and Opportunities}

\author{
SUBMMITED BY: \\ HASSAN HUSSEIN IBRAHIM \\ RNO: HKMDS 04412 \\ BACHLEOR IN ACCOUNTING (MOGADISHU UNIVERSITY)
}

A RESEARCH REPORT SUBMITED TO KAMPALA UNIVERSITY GRADUATE SCHOOL IN PARTIAL FULFILLMENT OF AN AWARD FOR A DEGREE IN MASTERS OF ARTS IN DEVELOPMENT STUDIES 


\section{DECLARATION}

"This thesis is the result of my original work and has not been presented for a degree or any other academic award in any university or institution of learning".

\section{Hassan Hussein Ibrahim}

Signed:

Date: 


\section{APPROVAL}

"I certify that this research Report satisfies the partial fulfillment of the requirements for the award of the Master's Degree in Development Studies at Kampala University”.

Mrs.: Monica A.Ssengendo

Title: Supervisor:

Signature:

Date: 


\section{DEDICATION}

This thesis is dedicated to my wife, Nasra Ali Abdinoor for her support, encouragement and constant love she has offered me, my lovely son Shuaib Hassan Hussein and the rest of my beloved family. 


\section{ACKNOWLEDGEMENTS}

The researcher thank Allah the way he has guided to him and given the ability, the knowledge and the time to write this thesis.

I would like to express my sincere gratitude and appreciation to many people who have helped me to produce and complete this research project.

I am deeply grateful to my supervisors, Mrs.: Monica A.Ssengendo of the graduate school of development studies at the University of Kampla for the continues guiding and support without her support this research won't be produced. I am also thanking to Prof Najib Sheikh Abdi and Hope University Team in Mogadishu for the facilitation of the Program.

My sincere thanks to my employer Norwegian refugee Council (NRC) Somalia program, especial thanks goes to my manager Opio peter Patrick and the entire staff for their moral and material support. Without your flexibility and financial support this project would have been difficult.

I want to thank my collogues at NRC, Sayid-ali Abdi Siyad, Mohamed Hussein Fidow, Daud Haji Abdi, Najma Eid and Nasra Hussein Abdi, especial thanks goes to Adam Ahmed and Abdinasir Gure for technical support in arranging this project, also thanks to Muktar Wardere and Dahir Mumin for their encouragement and continues support.

My heartfelt thanks and my love goes to my lovely wife, Nasro Ali Abdinur and my lovely boy shuibe Hassan Hussein for their patience, their unconditional love and their support; thank you for believing in me.

Mogadishu, October, 2014

Hassan Hussein Ibrahim 


\section{ABSTRACT}

This study comprises of five chapters. The topic of the research was Impact of Rural Urban Migration on Economic Sources in Mogadishu: Challenges and opportunities. The main objective of study was to examine determinates of rural urban migration in Somalia. Challenges and problems associated with internal rural migration and possible solutions of the problems associated with internal migration.

Methodology: The researcher employed a descriptive survey design and engaged both Quantitative and Qualitative Research methods and also used interview schedule and questionnaires for collecting data. The Quantitative Data, the researcher engaged the use of SPSS used by tables. While the Qualitative Data also analyzed by using themes and explanations while comparing and contrasting the findings with the literature review.

The sample size used to be 384 respondents picked up from the target population.

Key findings: Recurrent shocks both natural and manmade disasters including droughts, floods and conflicts are the major determinates of rural urban migration, High unemployment rates, limited educational facilities in the rural, lack of social service delivery including heath, medical facilities and clean water abject poverty and bad living conditions. The weakened Government efforts and NGOs to curb the problems of internal migration include: Improve the economic status of the country, support agricultural sector and livestock to keep the pastoral and agro-pastoralist to migrate into the urban areas. Reorganization and diversifying the Employment in public and private sectors to reduce the economic migration, specifically the youth migration from the rural to urban areas looking for better employment opportunities.

Conclusion: Overall, the objectives of the study were attained and it was thus concluded that, determinants of the rural urban migration are mainly economic reasons and standard of the living condition in the rural, as well as the deteriorated insecurity situations in most parts of south and central Somali regions where internal migrants are mainly migrated from, the researcher described this as the pull and push factors. The socioeconomic conditions of the rural areas and internal migrants were found to be worrisome. 
Table of contents

Cover page .999

Declaration. 1000

Approval. .1001

Dedication .1002

Aknowledgments. 1003

Abstract .1004

Table of contents 1005

Contents .1005

\section{CHAPTER ONE}

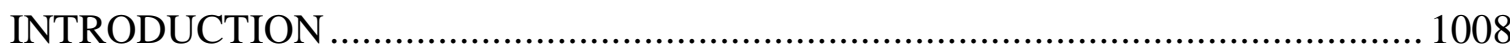

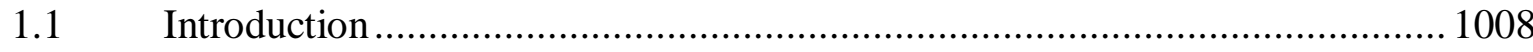

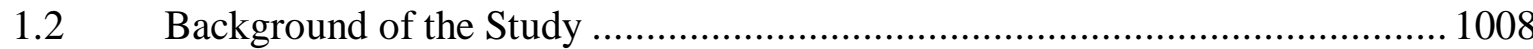

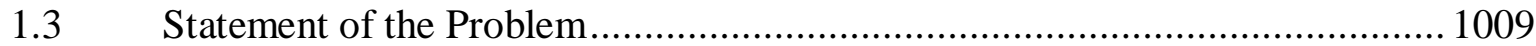

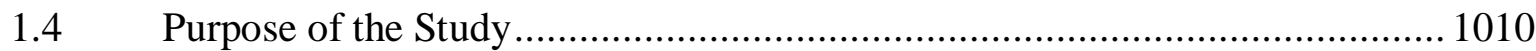

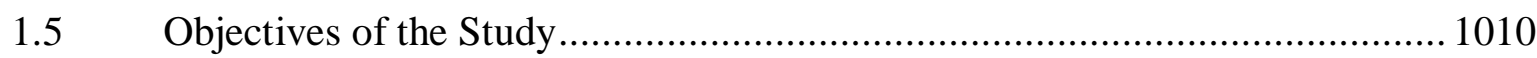

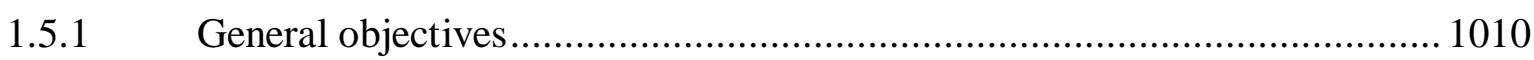

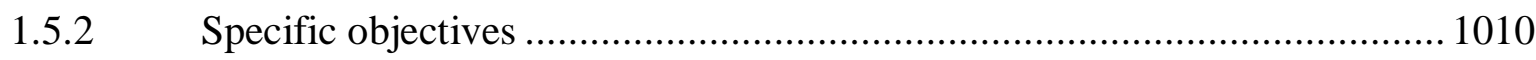

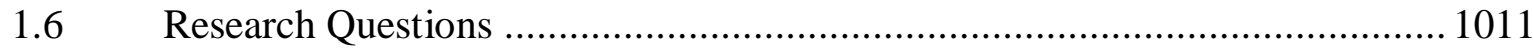

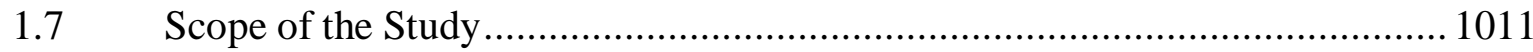

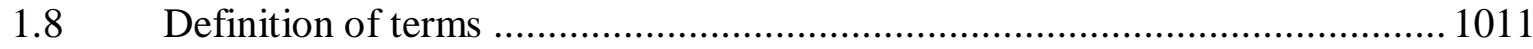

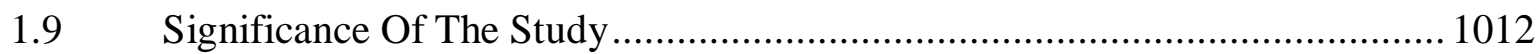

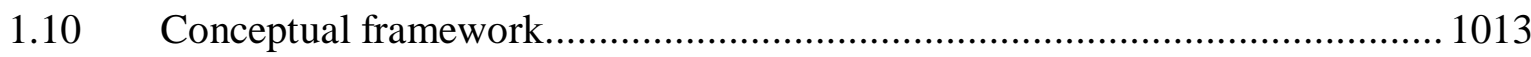

CHAPTER TWO: LITRATURE REVIEW .......................................................... 1014

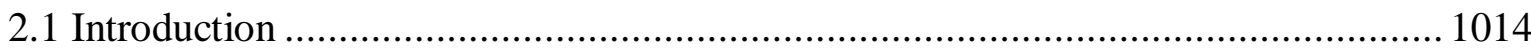

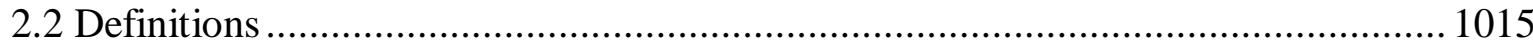

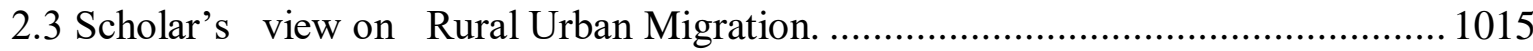

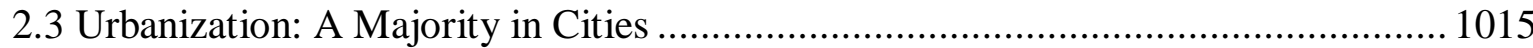

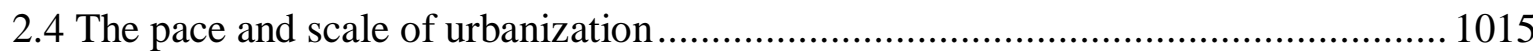

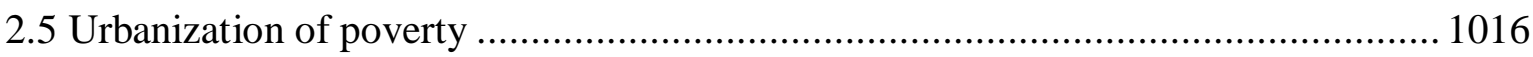

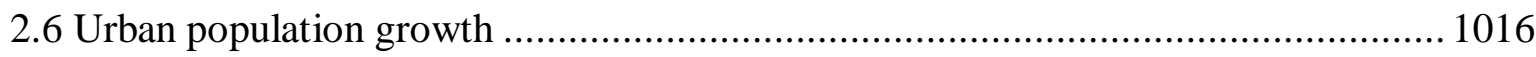

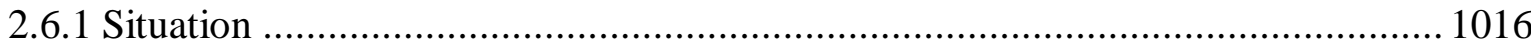


2.6.2 Trends 1017

2.7 Causes and effects of rural urban migration 1017

Section Two: Rural Urban Migration and Economic Impact .................................... 1018

2.8 Economic Reasoning of Rural Urban Migration .................................................... 1018

2.9 Push and Pull Factors of Rural Urban Migration ................................................... 1019

2.10 Labor Mobility to Economic Growth and Rural Urban Migration......................... 1020

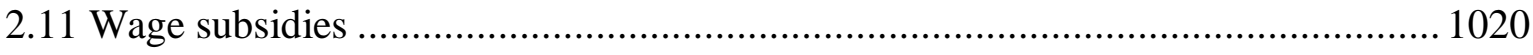

2.12 Employment Opportunities and Job Creation in Urban cities.............................. 1021

2.13 Challenges of Rural Urban Migration............................................................ 1022

CHAPTER THREE: METHODOLOGY ............................................................. 1024

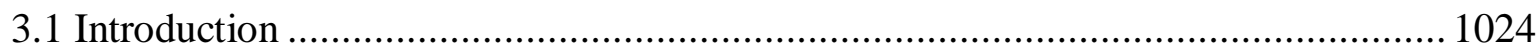

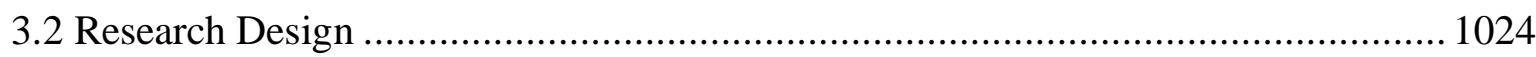

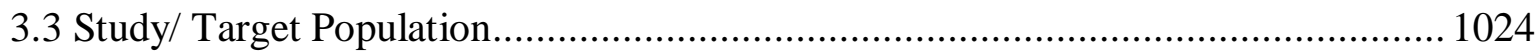

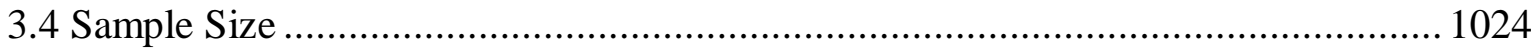

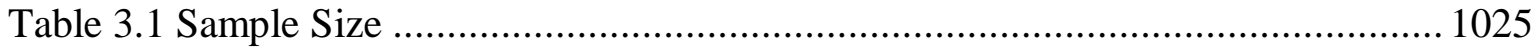

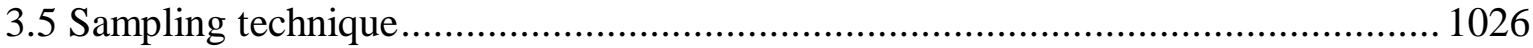

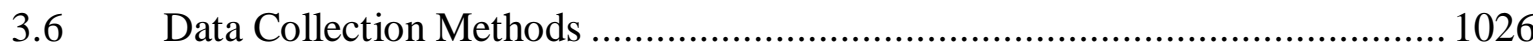

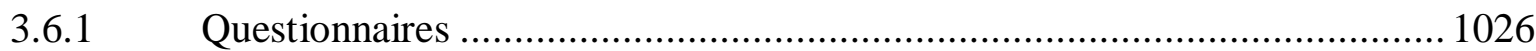

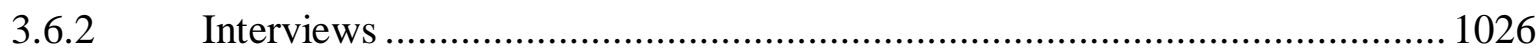

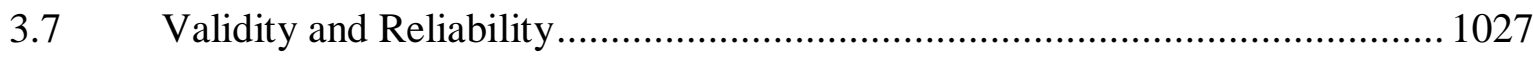

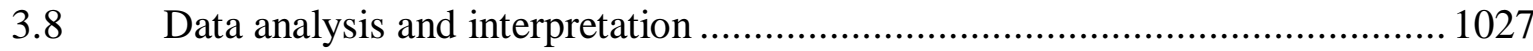

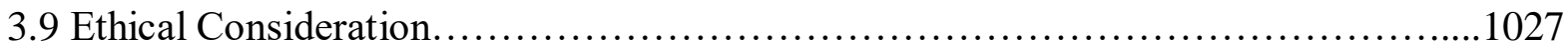

CHPATER FOUR: PRESENTATION, ANALYSIS, INTERPRETATION ADISSCUSSION OF THE FINDINGS.

4.1 Introduction. 1028

CHAPTER FIVE: SUMMARY OF FINDINGS, CONCLUTIONS

RECOMMENDATIONS ............................................... 1045

5.1 Introduction...................................................... 1045

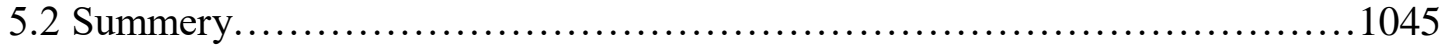

5.3 Conclution of findings.............................................. 1046

5.4 General Recommendation............................................. 1046

5.5 Areas for further research............................................. 1047

References.............................................................. 1048

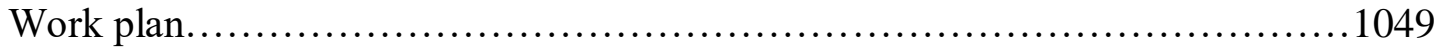


Budget Estimates. 1049

Appendix 1 Questionnaire 1050

Appendix 2 Interview Guide. .1053

List of Tables

4.1 Gender of the respondents. 1028

4.2 Segregation of respondents age. 1029

4.3 Marital status of the respondents 1030

4.4 Level of the Education of the respondents. 1031

4.5 Does your households living in Mogadishu. .

4.6 If yes for how long your house hold living in Mogadishu.

4.7 Have you even been migrated for your place of origin. 1033

4.8 If yes where are you migrated from.... 1033

4.9 What was the main reason of your migration from rural to urban 1034

4.10 Social Economic problems in your place of origin. .1035

4.11 Economic reasons and pushing factors encouraging on rural urban migration. 1036

4.12 Which gender is more likely to migrate on completion at any given level. .1037

4.13 Level of opportunities and economic sources in urban areas. 1038

4.14 Rural urban migration is copying strategy of the shocks. 1039

4.15 Are you know working in Mogadishu. 1039

4.16 If yes what is the type of your employment. 1040

4.17 What where working on when in your place of origin 1041

4.18 When you have come to Mogadishu would you met your expectations .1041

4.19 What is the impact of rural urban migration on economic sources. 1042

4.20 Challenges associated with internal migration. 1042

4.21 Did you think rural urban migration impact on rural urban product. 1043 


\section{CHAPTER ONE \\ INTRODUCTION}

\subsection{Introduction}

The migration of the people, particularly labor and man power from rural to urban areas is an important part of the urbanization Process in developing countries, Somali has been lack of government and effective system of governing, which might provide or administer social service, health facilities, access to free of education and equal employment opportunities among Somali people for the past two decades, which of course had a consequence of moving people from rural to urban areas to better life and bright future for the youth and man power.

This study is entitled to focus on impact of rural urban migration on mobilizing local economic sources and opportunities in Somalia, where Mogadishu the capital city of Somali is under study on impending migrants from rural as the economic zone for employment opportunities and better services other than rest of Somali urban towns. Even though the existing of insecurity is questionable, the study examined only economic perspective and sources of opportunities that might attract to migrate from the place of origin to the urban areas and the green side.

\subsection{Background of the Study}

In developing economies, structural changes often have profound spatial implications. The present survey focuses on labor-related migration from rural to urban areas, a general pattern which plays a central role in the urbanization process and is often viewed as the labor market adjustment to the inter scrotal shift in importance from agriculture to manufacturing and services. The migration decision has been shown to be selective. Migration mainly concerns young adults who are more likely to have a positive net expected return on migration due to their longer remaining life expectancy, or because social norms require that young adults migrate in search of a better life (De Haan and Rogally, 2002). Family strategies can involve sending young adults to the city, and investing in a potentially remitting child (Lucas and Stark, 1985). Both low and high skilled individuals are more likely to migrate but usually for different reasons: "surplus" lowskilled individuals have strong incentives to move to the city in search of a manual job they may not find in the rural area, while "scarce" educated workers may find that their human capital is better rewarded in cities than in rural areas (Lanzona, 1998, Agesa, 2001). In most countries, internal migration concerns young men because urban job markets usually offer a large share of occupations available to rural male migrants, or because men bear lower risks of vulnerability than women when migrating. 
The decision to migrate also involves contextual factors, such as 'push factors' which force migrants out of rural areas and 'pull factors' which attract migrants to urban areas. These factors typically reflect the relative strength of the local economies (Such as availability and remuneration of jobs) in urban areas.

Due to many reasons there was a fellow of regular migrations from the rural and per-urban areas to the urban and large cities in Somalia; Mogadishu (Capital city of Somali) has been hosting migrants from rural because of limited service provision (education, health and availability of clean water Etc) and economic migration due to shortage of employment opportunities and casual work in the rural areas.

As migration overall in an ancient phenomena of migrating from one place to another for better life and future of the upcoming generation to be able to meet basic rights for education, health and social services Somali families are literally migrating, when we look at the studies of Somalia we see that Somalis has historical culture of nomadic and movement on the grass and water availability to their rearing animals. This has affected to the urban and entire cycle of Somali urbanization in terms of potentiality and easy migration to seek resources and look at the green side and opportunities without affecting on their culture, values and certain areas, but this has left problems in the rural area according to the Michael J. Greenwood, which also applies to Somalia case.

"The inhabitants of the country immediately surrounding a town of rapid growth, flock into it; the gaps thus left in the rural population are filled up by migrants from more remote districts, until the attractive force of one of our rapidly growing cities makes its influence felt, step by step, to the most remote corner of the kingdom. Migrants enumerated in a certain centre of absorption will consequently grow less with the distance proportionately to the native population which furnishes them, and a map exhibiting by tints the recruiting process of any town ought clearly to demonstrate this fact. That this is actually the case will be found by referring to maps $3,4,8$, and 9 . These maps show at the same time that facilities of communication may frequently countervail the disadvantages of distance."

\subsection{Statement of the Problem}

Migration of population in and outside of their areas of origin could be considered as a normal course in search for their daily bread since Somalia became a failed state in 1991. Lack of the service provision in all regions of Somalia caused rural urban migration supposedly in search for better life and better economic and social opportunities and safety which could be as important in the Somalia case. There are many people coming regularly in Mogadishu which is the case study in this research. Undoubtedly, not all the migrations 
to Mogadishu from rural areas has economic and services seeking dimensions, there is much attributed to insecurity as people look for better life.

This research is intended to investigate the impact of rural urban migration on mobilizing local economic sources and opportunities in Somali, despite inadequate employment opportunities and lack of effective employment agencies that can be equally treated to the job seekers, the study will look at how the rural-urban migrants mobilize economic sources to sustain and adapt the life in Mogadishu. Rural-urban migration has also created social problems on rural based production and reduced the integration and economic interdependence of the rural urban cycle as depicted on population density in Mogadishu.

So, this study analyzed the major push factors for rural-urban migration in Somalia; why Mogadishu is an attractive city for internal migrants. How do rural migrants to urban Mogadishu create and mobilize new economic opportunities that had not been seen by those who were there so many years and converting these new opportunities into sustainable income sources to the migrants. Not only the positive aspects but also the density of the population especially the new ones and how the hosted communities interact with people who had come to Mogadishu earlier.

\subsection{Purpose of the Study}

This study described on the impact of rural urban migration on mobilizing local economic sources and opportunities in Somali, challenges and merits on both rural and urban areas.

\subsection{Objectives of the Study}

The study will be guided by both general and specific objectives.

\subsubsection{General objectives}

The general objective of the study is to describe the related opportunities and challenges of rural urban migration in mobilizing local economic sources in Mogadishu-Somalia.

\subsubsection{Specific objectives}

This study will be guided by the following specific objectives:

1) To describe social determinants of rural urban migration in Somali.

2) To identify the level of opportunities and economic sources that can be attractive factors for internal rural urban migration in Somali

3) To assess the challenges associated with internal migration 
4) To find out solutions to the problems associated with rural-urban migration

\subsection{Research Questions}

1. What are the social determinants of rural urban migration in Somali?

2. What is the level of opportunities and economic sources that can be attractive factors for internal rural urban migration in Somali?

3. What are the challenges associated with internal migration?

4. What are the solutions to the problems associated with rural-urban migration?

\subsection{Scope of the Study}

Content scope: this study was assessed the impact of rural-urban migration, paying particular attention to the challenges and opportunities associated with these movements.

Geographical scope: The study was conducted in Mogadishu, the capital city of Somalia.

Time scope: The study was assessed the variables under study for the period 2008 to 2012

\subsection{Definition of terms}

The terms of the research tile both independent and dependent variables and are defined in the following:

Rural: is the comprehensive, nonspecific word referring to life on the farm or in the country as distinguished from life in the city (Webster's New World Dictionary).

Urban: Is the characteristic of the city as distinguished from the rural, in US census use designating or of incorporated or unincorporated place with at least 50,000 inhabitants (Webster's New World Dictionary).

Migration: is the movement of people from one place to another, according to the UN Habitat (Report 2008).

Urbanization is the physical growth of urban areas into rural or natural land as a result of population inmigration to an existing urban area. Effects include change in density and administration services. While the exact definition and population size of urbanized areas varies among different countries, urbanization is attributed to growth of cities. Urbanization is also defined by the United Nations as movement of people from rural to urban areas with population growth equating to urban migration UN FAO (2008). 
Economics is the social science that studies the behavior of individuals, households, and organizations (called economic actors, players, or agents), when they manage or use scarce resources, which have alternative uses, to achieve desired ends. Agents are assumed to act rationally, have multiple desirable ends in sight, limited resources to obtain these ends, a set of stable preferences, a definite overall guiding objective, and the capability of making a choice. There exists an economic problem, subject to study by economic science, when a decision (choice) is made by one or more resource-controlling players to attain the best possible outcome under bounded rational conditions. In other words, resource-controlling agents maximize value subject to the constraints imposed by the information the agents have, their cognitive limitations, and the finite amount of time they have to make and execute a decision. Economic science centers on the activities of the economic agents that comprise society, they are the focus of economic analysis. Harper (November 2001).

\subsection{Significance of the Study}

This study provided sufficient information on the problem of rural urban Migration. It will also be a reference for many researchers, including students, Civil Society organizations and government agencies, and even other people who have close interest on the subject matter to solve this social problems.

The focus of the research was concerned government agencies particularly mainstay of labor and planning which the findings of this research will be important according to the essentiality and close interest to them, to kick this problem out the social boarder.

The researcher on the subject matter also referred to this study as a literature review and as bases for other researches in the similar field of study. The work can also be of significance to the general population and to the educated youths in particular when they come across it. 


\subsection{Conceptual framework}

\begin{tabular}{|c|c|c|}
\hline & & 7 \\
\hline Independent Variables & Intervening Variable & Dependent Variables \\
\hline $\begin{array}{l}\text { Rural Urban Migration } \\
\text { - Urbanization and Growth of } \\
\text { the scale of the cities. } \\
\text { - Pushing Factors and critical } \\
\text { life in the Rural areas } \\
\text { - Limited Service provision in } \\
\text { the rural areas. } \\
\text { - Conflicts and insecurities. } \\
\text { - Droughts and Climate } \\
\text { Change. }\end{array}$ & $\begin{array}{l}\text { Moderating Variable } \\
\text { - Culture and } \\
\text { diversity. } \\
\text { - Urbanization. } \\
\text { - } \quad \text { Snooping and } \\
\text { Social Status. } \\
\text { - Security \& } \\
\text { Conflict. } \\
\text { - } \quad \text { Acceptance }\end{array}$ & $\begin{array}{l}\text { Economic Sources and } \\
\text { Opportunities } \\
\text { - Employment opportunities } \\
\text { in Mogadishu. } \\
\text { - Availability of Services in } \\
\text { Mogadishu ( health \& } \\
\text { Education ) } \\
\text { - Acceptable and incentives } \\
\text { and Wages for the workers } \\
\text { and Casual Labors. } \\
\text { - Markets. } \\
\text { - Business and innovative } \\
\text { society }\end{array}$ \\
\hline
\end{tabular}

\section{Source: Researcher}

The above diagram indicates the relation between the variables of the study, independent variable, dependent and intervening variables, the larger scale of the urbanization, the critical life in the rural areas of Somali and the prolonging conflicts of inter-clans and political dynamics in Somali has an impact associated with massive rural urban migration from all over south and central Somali region and it has also an impact of the limited economic sources and opportunities in Mogadishu. As the diagram shows the researcher demonstrating other variables which has a relative effect on dependent variable, as wells as contributing to the rural urban migration. 


\section{CHAPTER TWO \\ LITRATURE REVIEW}

\subsection{Introduction}

The review of literature in this study is intended to assess the impact of rural urban migration on mobilizing local economic sources and opportunities in Somalia. However; the literature has been reviewed in according to the importance of the research title to solve the social and economic problems, which hopefully the research will be treated or contributed in regard to the problem of the research and objectives of the study that has been mentioned.

This chapter will cover on three sections, first the scholar's view of rural urban migration, urbanization, growth of urban cities and rural concepts. Second the economic impact of rural urban migration; opportunities in urban areas (pull Factors). Thirds the societal change of rural urban migration both challenges and opportunities.

\section{Section One: Reasoning on People's Migration}

Rural development initiatives across the developing world are designed to improve community wellbeing and livelihoods. However they may also have unforeseen consequences, in some cases placing further demands on stretched public services. In this paper we use data from a longitudinal study to investigate the impact of a recent rural development initiative, installing village-level water taps, on rural to urban migration of young adults.

Young adults with access to this rural development intervention had three times the relative risk of migrating to urban centres compared to those without the development. We also identify that family dynamics, specifically sibling competition for limited household resources (e.g. food, heritable land and marriage opportunities), are key to understanding the timing of out-migration. Birth of a younger sibling doubled the odds of out-migration and starting married life reduced it. Rural out-migration appears to be a response to increasing rural resource scarcity, principally competition for agricultural land. Strategies for livelihood diversification include education and off-farm casual wage-labour. However, jobs and services are limited in urban centres, few migrants send large cash remittances back to their families, and most return to their villages within one year without advanced qualifications. One benefit for returning migrants may be through enhanced social prestige and mate-acquisition on return to rural areas. These findings have wide implications for current understanding of the processes which initiate rural-to-urban migration and 
transitions to low fertility, as well as for the design and implementation of development intervention across the rural and urban developing world. Eshetu Gurmu (2012).

\subsection{Urbanization: A Majority in Cities}

The world is undergoing the largest wave of urban growth in history. In 2008, for the first time in history, more than half of the world's population will be living in towns and cities. By 2030 this number will swell to almost 5 billion, with urban growth concentrated in Africa and Asia. While mega-cities have captured much public attention, most of the new growth will occur in smaller towns and cities, which have fewer resources to respond to the magnitude of the change.

In principle, cities offer a more favorable setting for the resolution of social and environmental problems than rural areas. Cities generate jobs and income. With good governance, they can deliver education, health care and other services more efficiently than less densely settled areas simply because of their advantages of scale and proximity.

Cities also present opportunities for social mobilization and women's empowerment. And the density of urban life can relieve pressure on natural habitats and areas of biodiversity. The challenge for the next few decades is learning how to exploit the possibilities urbanization offers. The future of humanity depends on it, according to Rudzitis (1989).

\subsection{The pace and scale of urbanization}

Urban growth, which is mostly due to natural increase, is inevitable. However, the speed and size of the growth are not fixed, and vary widely among regions. The most effective way to slow rates of urban growth is to reduce unwanted fertility in both rural and urban areas. Lowering poverty, empowering women and providing quality reproductive health services all influence fertility preferences and ability to meet them.

Fertility rates are lower in urban than in rural areas throughout the world. However, the fact those large percentages of people in many developing countries are young means that urban population growth will continue rapidly for years to come. Moreover, impoverished urban women are significantly less likely than their more affluent counterparts to have access to reproductive health or contraception. Not surprisingly, they have higher fertility rates.

Migration is a significant contributor to urbanization, as people move in search of social and economic opportunity. Environmental degradation and conflict may drive people off the land. Often people who leave 
the countryside to find better lives in the city have no choice but to settle in shantytowns and slums, where they lack access to decent housing and sanitation, health care and education - in effect, trading in rural for urban poverty, according to the Gundars (1990).

\subsection{Urbanization of poverty}

Poverty is now growing faster in urban than in rural areas. One billion people live in urban slums, which are typically overcrowded, polluted and dangerous, and lack basic services such as clean water and sanitation.

Although urbanization increasingly concentrates poverty, it also provides possibilities for escaping it. For the most part, rich countries are already urbanized, and most of the expected urban growth will occur in less-developed regions, which have fewer resources for coping with the scale of the change.

In the Millennium Declaration, the international community recognized that to halve by 2015 the proportion of people living in extreme poverty, it will have to directly address the needs of the burgeoning population of poor people living in cities. One of the targets set by world leaders in 2000 was to improve significantly the lives of at least 100 million slum dwellers by 2020. Addressing the housing needs of the urban poor will be critical. A roof and an address in a habitable area are the first step to a better life. Improving access to basic social and health services, including reproductive health care, for poor people in urban slums is also critical to breaking the cycle of poverty.

\subsection{Urban population growth}

\subsubsection{Situation}

Urbanization, the demographic transition from rural to urban, is associated with shifts from an agriculture-based economy to mass industry, technology, and service, For the first time ever, the majority of the world's population lives in a city, and this proportion continues to grow. One hundred years ago, 2 out of every 10 people lived in an urban area. By 1990, less than $40 \%$ of the global population lived in a city, but as of 2010, more than half of all people live in an urban area. By 2030, 6 out of every 10 people will live in a city, and by 2050, this proportion will increase to 7 out of 10 people. Currently, around half of all urban dwellers live in cities with between 100000 - 500000 people, and fewer than $10 \%$ of urban dwellers live in megacities according to UN HABITAT (2010) 


\subsubsection{Trends}

Globally, urban growth peaked in the 1950s, with a population expansion of more than $3 \%$ per year. Today, the number of urban residents is growing by nearly 60 million every year. The global urban population is expected to grow roughly $1.5 \%$ per year, between 2025-2030. By the middle of the 21 st century, the urban population will almost double, increasing from approximately 3.4 billion in 2009 to 6.4 billion in 2050. Almost all urban population growth in the next 30 years will occur in cities of de veloping countries. Between 1995 and 2005, the urban population of developing countries grew by an average of 1.2 million people per week, or around 165000 people every day. By the middle of the 21st century, it is estimated that the urban population of these counties will more than double, increasing from 2.5 billion in 2009 to almost 5.2 billion in 2050. Nonetheless, on average, the rate of urban population growth is slowing in developing countries, from annual rate of roughly 4\% from 1950-1975 to a projected $1.55 \%$ per year from 2025-2050. In high-income countries, on the other had, the urban population is expected to remain largely unchanged over the next two decades, increasing from 920 million people to just over 1 billion by 2025 . In these countries, immigration (legal and illegal) will account for more than two-thirds of urban growth. Without immigration, the urban population in these countries would most likely decline or remain static, according to WHO (2007).

\subsection{Causes and effects of rural urban migration}

One noticeable issue in the society today is the rate at which people (including youths and adults) migrate from the rural to the urban areas. Like a paradox, while the cities (urban areas) are increasing in population, the rural areas are decreasing.

One of the factors that is responsible for rural -urban migration is lack of / inadequate social amenities and facilities in the rural areas. These include pipe borne water, electricity, good roads, hospitals, schools, recreational centers (like Stadiun, Zoo, Amusement park) among others. Inadequate jobs in the rural areas also make many youths to migrate to the urban areas that can provide better opportunities for them.

Rural-urban migration has negative consequences. It leads to overpopulation of the urban areas thus encouraging crime in the society. Those who engage in crime prefer the urban areas being turgid with wealthy individuals.

Rural -urban migration slows down the rate of development of the rural areas. In view of the negative consequences, Government of each country in the world should strive to Provide social amenities and 
facilities in the rural areas and also provide jobs for the citizens in the rural areas according to Akindelly, (Nove, 2009).

\section{Section Two: Rural Urban Migration and Economic Impact}

In this section concepts on rural urban migration in relation to the economic impact will be discussed, pushing factors and pulling factors, labor motilities and urban opportunities.

\subsection{Economic Reasoning of Rural Urban Migration}

In many countries, particularly in third world countries there is a noticeable pattern of rural to urban migration. This pattern of migration is not a new phenomenon.

There are various reasons for its occurrence and these reasons may vary from country to country and over periods of time. The consequences of this type of migration however similar results for different countries and over periods of time have.

One cause of rural to urban migration may be the lack of jobs in the area. Many of the jobs available in rural areas are agricultural based. The introduction of labour saving devices and bad weather conditions has decreased the demand for labour in the agricultural sector. The decrease in the traditional form of employment in rural areas forces many young people to leave the area in search of work in the urban centers of their country.

Workers may also migrate from rural areas to urban areas in hope of gaining a higher standard of living. They may leave their current jobs in hope of finding higher paying ones as there are many more opportunities for employment to choose from in the city.

A third reason for this pattern of migration is that many people desire to expand their experiences. They may wish to be exposed to a greater variety of opportunities, people, cultures, art, food and entertainment. The variety they desire may not be as widely or conveniently available to them in their hometowns as in an urban center in their country.

War, famine and natural disaster are also reasons for rural to urban migration in some countries. Entire rural populations may migrate to the urban centers of their country in search of protection, food and medical aid during these periods of hardship. 
One consequence of rural to urban migration is overcrowding. If migration takes place too quickly or unexpectedly, the planning necessary to accommodate growth will not be in place. Overcrowding leads to issues such as higher rents, traffic and pressure on resources

Such as schools and medical centers

The growth in the working population will also mean more competition for jobs. This will prove advantageous to employers who can decrease salaries offered as demand for jobs may outstrip the number of jobs available. The lack of jobs may in turn lead to problems of vagrancy, prostitution and unfair treatment to the least skilled workers in the workforce.

The migration of people from rural areas to urban areas has detrimental effects on the rural economy. Some small communities may cease to exist overtime as there is no one left to run businesses, work in local companies or demand products from local firms because the younger generations of the area have migrated.

Lastly, there may be an increase in the spread of diseases from urban to rural areas, when workers return home to visit relatives and friends they may spread illnesses and diseases they contracted while in the city. This accounts for the spread of AIDS in rural areas of many African countries.

Migration from rural to urban areas occurs for several reasons, namely in the search of a better lifestyle and standard of living. However planning is necessary to properly provide for the additional strain that a growing population will have on a city's resources. Planning may also be necessary to protect rural communities and aid their growth as a solution to the overcrowding that occurs in most urban centers in countries around the world.

\subsection{Push and Pull Factors of Rural Urban Migration}

\begin{tabular}{|ll|ll|}
\hline Push & & \multicolumn{2}{l|}{ Pull } \\
\hline$\bullet$ & Famine, Drought, natural disasters. & $\bullet$ & Employment \\
$\bullet \quad$ & Poor Living Conditions - housing, & $\bullet$ & Higher Incomes \\
education and health Care, & $\bullet$ & Better Health Care and Education \\
$\bullet \quad$ & Agricultural Change. & $\bullet$ & Urban Facilities and Way of Life \\
$\bullet$ & Unemployment & $\bullet$ & Protection From Conflict \\
$\bullet$ & War and Conflict & & \\
\hline
\end{tabular}




\subsection{Labor Mobility to Economic Growth and Rural Urban Migration}

Population migration and labor mobility are characterized not only as a momentum of economic transformation from an agriculture-dominated economy to an industrial one, a common phenomenon in developing countries, but also as a unique economic transition

From a planned economy to a market economy, constituting an important source of China's rapid economic growth during the reform era

According to the neo-classical theory of factors equalization theory, the increase of and rural to urban migration should have an impact of narrowing regional and rural-urban disparities, but an opposite outcome has been observed since 1990s) incorporated the variable of marketization into a gravity model and found that the market-oriented reform has created an institutional environment favoring labor mobility and directing the spatial distribution of rural to urban migration. Lin el al. (2004) also used a gravity model and confirmed that migration become more responsive to regional disparity. The elasticity of migration to income disparity rose from 0.197 during 1985-1990 to 0.595 during 1995-2000. The reason that increasing mobility hasn't reduced income inequality mainly comes from the unfinished hukou system and other factors that continue to enlarge regional disparity. Cai and Wang (2003).

\subsection{Wage subsidies}

Since the inefficiency in the Harris-Todaro model comes from wage rigidity, another Policy emerging from the analysis is to reform wages. In the Harris-Todaro perspective, Reforms that make urban wages less rigid should bring the allocation of labor in the Economy close to the optimum. Alternately, taking the wage rigidity as given, policy Reforms arising from welfare analysis focus on wage subsidies. Harris and Todaro (1970).

Considered the case of a wage subsidy to the urban sector alone, showing that it cannot Restore the social optimum and causes suboptimal employment in the rural sector because of induced migration, With this instrument, the best that can be done is to ensure that urban jobs are created until the marginal productivity in the urban sector equates the Marginal amount of rural output sacrificed because of migration (i.e. the marginal Productivity in the rural sector multiplied by the number of migrants induced by the Creation of a single additional urban job). Combining an urban wage subsidy and

Migration restrictions can move the economy to a greater aggregate welfare by simultaneously increasing the urban output through wage subsidies and preventing the Exacerbation of unemployment 
through migration restrictions. However, pointed out, this policy will require a substantial compensation to the rural urban migration as Harris and Todaro (1970)

\subsection{Employment Opportunities and Job Creation in Urban cities}

One of the key factors of rural-urban migration is the lack of employment in rural areas, increasing exponentially the ever-growing challenges related to providing adequate basic infrastructure to a growing number of unplanned low-income urban settlements. The lack of reliable infrastructure assets in rural areas leading to the lack of access to basic social services, markets and job opportunities, often force the local rural population to migrate. Rural and urban development strategies can be explicitly made more pro-poor by optimizing the employment impact of physical upgrading strategies in infrastructure and service delivery, providing social-safety nets, and other alternatives in the form of unemployment insurance, micro financing or job training. The ILO encourages municipalities to provide quality rural and urban services in ways that improve access for the poor while creating decent jobs and promoting entrepreneurship.

The Employment-Intensive Investment Unit (EMP/INVEST) has been successful in combining the objective of improving infrastructure and services with the objective of creating employment and income. It promotes job rich growth in both rural and urban areas by increasing the employment-content of public and private investments in infrastructure through the redirecting of fiscal policies, strengthening governance in tendering and contracting processes and promoting good management practices, putting efforts to engage and upgrade local labour and through the choice of technology. Over thirty years of experience have shown that labour-based approaches and the targeted promotion of local small enterprises and community groups can be effective if mainstreamed in the planning, design, construction/delivery and maintenance of infrastructure and social services. Today,

More than 50 countries are applying procedures and tools developed by the EMP/INVEST in the areas of community participation and planning, labour-based or local resource-based technology and small-scale and community contracting.

The ILO's Social Finance Program (SFP) promotes sustainable finance with a social goal, including credit, savings and other products that help the poor to cope better with risk, take advantage of incomegenerating opportunities, organize and have a voice. Social finance is also about promoting and encouraging those institutions that cater to the financial needs of the working poor, including women's groups and small and medium enterprises that create jobs. The aim is to promote policies that open up the financial sector to the working. 
Majority and create an enabling environment in which microfinance institutions can operate. The Program addresses three major goals: reducing vulnerability, and increasing access to risk management tools, creating jobs through enterprise development, and making financial policies more employmentsensitive.

\subsection{Challenges of Rural Urban Migration}

In fact, there is nothing particularly unusual about the dynamics of Africa's urban transition once the true underlying forces driving the process are understood.

Economists have assumed for decades that individuals decide to move from rural to urban areas primarily in the hope of getting a job. It follows that the prospect of getting a job (i.e. economic conditions) should correlate with urbanization. Empirical research has provided very tenuous evidence in support of such a link. Why?

A wealth of anthropological and sociological studies have shown that people also choose to migrate for a variety of non-economic reasons, including a desire to escape age or gender discrimination in their communities, to find a wife or husband, to seek adventure in the "bright lights" of the big city, or to escape rural serfdom. In medieval Germany, there was a saying that "city air makes you free". As a result, migration trends are far less sensitive to economic trends than the traditional model of urbanization predicts. In other words, there are always individuals who have a reason to migrate to cities regardless of prevailing economic circumstances. It is therefore no surprise that rural-urban migration (and hence urbanization) persists in the face of economic stagnation.

But this does not explain the exceptional rates of urban population growth seen across Africa. As noted above, rates of urbanization (driven by rural-urban migration) in the regions are not particularly rapid. So where are all these people coming from? The answer is that the majority of Africa's expanding urban populations are born in cities, not in villages.

To make a long story short, there have been significant improvements in life expectancy in urban and rural areas across Africa since the 1940s as a result of technological and institutional changes that have reduced disease-related mortality and improved food security. Due to persistently high fertility rates, this has led to a population boom of historically unprecedented proportions. While this may be contributing to rural out-migration due to population pressure in rural areas, it is also driving rapid population growth in urban 
areas that is wholly independent of migration. Simply put, the rapid Growth of Africa's urban population is being driven primarily by rapid population growth in urban areas, not rural-urban migration.

From a practical perspective, the pressing challenges of providing adequate housing, infrastructure, employment opportunities and security in African cities relate to rapid urban population growth, not urbanization. And yet governments and aid agencies have mistakenly sought to deal with these challenges by targeting rural-urban migration based on a misunderstanding of the dynamics shaping Africa's urban transition. For those interested in easing demographic pressure in urban areas, the only humane policy option is to try to reduce population growth by promoting fertility decline through voluntary family planning initiatives. And for those interested in promoting economic development in the region, investment in urban areas should be top of the policy agenda. 


\section{CHAPTER THREE \\ METHODOLOGY}

\subsection{Introduction}

This chapter covered various items. These included Research design, study area and population, sample size, sampling technique, data collection methods, research instruments, data collection and data analysis.

\subsection{Research Design}

The study is titled on the impact of rural urban migration on economic sources in MogadishuChallenges and an opportunity in Somali- Mogadishu was under study, in this study, an analytical study design was applied. An analytical study design is a type of research study design where either the entire population or a subset thereof is analyzed for the purposes of collecting data for answering specific research questions (Albright, 2005). It is called cross-sectional because the information about the variables being investigated is gathered represents what is going on at only one point in time. This study design was used because it is easy to use as the information collected from respondents would not be required to be reinvestigated over a period of time.

\subsection{Study/ Target Population}

The study was targeted migrants from rural to urban especially Mogadishu specifically rural urban migrants in Mogadishu, 372,000 according to UNHCR Report on 2012 as the population that constituted mainly different age groups youth and elders and also gender bases men, female. Boys and girls, In this study the focus will be economic migrants and people who are pursing the financial opportunities in Mogadishu those who can mobilize the economic and non economic opportunities in Mogadishu. The focus also will be on youth, casual labors, student, small business workers and professional migrants employed in Mogadishu.

\subsection{Sample Size}

The sample size was 384 respondents drawn from the categories of respondents in the study area and population. The respondents were categorized into three major categories. The first category included general migrants, casual labors, business groups, aid seekers, and especial migrant interests. The second category will be service seeker's migrants' students and health seekers or people live chronic diseases. The third category is professional migrants. 
Salant and Dillman (1994) defined a sample as a set of respondents selected from a larger population for the purpose of a survey.

Since the target population is large enough, sample size determination was based on a formula developed by Cochran (1963:75) stated as follows;

Where $\mathrm{n}_{\mathrm{o}}$ - required sample

$$
n_{\mathrm{o}}=\frac{\mathrm{Z}^{2} p q}{e^{2}}
$$

$\mathrm{Z}^{2}$ - Abscissa of the normal curve that cuts off an area $\alpha$ at the tails $(1-\alpha$ equals the desired confidence level, i.e. $95 \%$ )

e - Desired level of precision i.e. +/- 0.07

$\mathrm{p}$ - Estimated proportion of an attribute that is present in the population and $\mathrm{q}$ is $1-\mathrm{p}$.

The value for $\mathrm{Z}$ is found in statistical tables which contain the area under the normal curve. The confidence level determines how sure the researcher regards the result of the study and is expressed as a percentage. The $95 \%$ confidence level thus means that the researcher can be $95 \%$ confident of the level of accuracy of her results.

The confidence interval means the margin of error, which is always the plus, or minus figure usually in the calculator (Creative Research System, 2009). It is a specific interval estimate of a parameter determined by using data obtained from a sample and by using the specific confidence level estimate (Allan G. Bluman, 2004 p.328).

The sample size will be calculated as:

$$
\boldsymbol{n}_{\circ}=\frac{(1.96)^{2}(0.5)(0.5)}{(0.05)^{2}}=384 \text { Respondents }
$$

\begin{tabular}{|l|l|l|}
\hline No. & Category & sample \\
\hline 1. & Women & 100 \\
\hline 2. & Men & 100 \\
\hline 3. & Youths & 100 \\
\hline 4. & Others & 84 \\
\hline & Total & $\mathbf{3 8 4}$ \\
\hline
\end{tabular}




\subsection{Sampling technique}

Sampling in this study has taken two forms namely purposive sampling and simple random sampling. The purposive sampling method is the sampling technique where the sample size is derived by use of judgment of the researcher (Amin, 2005). This method shall use because it allows the researcher to choose certain respondents for supplying key information. The simple random sampling technique was selected because the sample size contains big number of respondents that require being appropriately and proportionately represented.

\subsection{Data Collection Methods}

The collection of data in this study has taken two forms, namely the collection of primary data and the collection of secondary data. The collection of primary data involved the use of questionnaires to gather information from the selected respondents as well as use of interview guide from the selected key informants. The collection of secondary data involved review of the official documents in which the researcher is extracted the secondary data of this study, books, publications and internet sources has been used to extract the literature of this research.

\subsubsection{Questionnaires}

The questionnaire is a research instrument with preset questions and guided style of response that was used to collect data from respondents (Amin, 2005). This instrument contained both open-ended questions and close-ended questions. The questionnaire will be applied to professional migrants or skill migrants, students and especial interest migrants. The questionnaire was selected for use in this study because it is easy to apply as most respondents were well educated and can fill in the questions easily or with little guidance.

\subsubsection{Interviews}

An interview guide was used. This is an instrument where mostly general questions are used to collect data mainly from key respondents (Amin, 2005). This instrument also contained open-ended questions as well as close-ended questions. The interview guide will be used for this study because some sections of the study population have more knowledge that cannot be fully captured using a questionnaire. These shall be referred to in this study as key informants such as Service Providers, Local and International NOGs, Construction Companies and other business Companies. 


\subsection{Validity and Reliability}

On one hand, the validity of the instruments, which are questionnaire and interview guide, will be measured. Validity of the instrument means the ability of an instrument to measure what it was intended to measure. In this study, the validity of the instruments was measured by a panel of experts through an assessment of selected items in the instruments that would ensure that the instrument was measuring to the expectations. After identifying the vague and ambiguous questions, corrections were made and a final instrument was prepared. On the other hand, the reliability of an instrument was measured. Reliability of the instrument means the consistence of the instrument in picking the needed information. It was measured by using the Inter-Rater Reliability (IRR) test. Two experts (raters) was used to rate the consistence of the instruments to measure the attributes they were designed to measure.

\subsection{Data analysis and interpretation}

Data processing is the method of separating of not needed data from the data that was used in data analysis (Amin, 2005). . This was done through editing of the data to check for accuracy, consistency, legibility and comprehensiveness. Then, data was then coded for further data analysis. Data analysis utilized two techniques, namely the quantitative data analysis and qualitative data analysis. In the quantitative data analysis, the data collected was coded first before it is entered into the computer. The data entered into the computer was analyzed using a computer program called Statistical Program for Social Sciences (SPSS). Under this program, data was analyzed using the method of frequency tabulation whereby counts/.tallies and their corresponding percentages were generated. It is upon these percentages that writing the final results report was based as well as analysis and interpretation. For qualitative data analysis, data was analyzed thematically through identifying themes that reflect the objectives and research questions of the study.

\subsection{Ethical Consideration}

- The researcher will not force respondents to give information. Instead he will obtain a formal consent as a pre-requisite to gathering information from the respondents.

- The researcher will produce an introductory letter from university which he will take to Banadir Regional Administration of the Somali Federal government to permit him to carry out research in this particular area.

- Participants will be informed in advance that all information collected through interviews or questionnaires will be treated with outmost confidentiality and the findings will not be used for any other purpose other than that indicated in the study. 


\section{CHPATER FOUR}

\section{PRESENTATION, ANALYSIS, INTERPRETATION AND DISSCUSSION OF THE FINDINGS}

\section{$\underline{\text { Introduction }}$}

This chapter presents the results of the study, which are presented, interpreted, analyzed and discussed, sequentially according to the objectives of the study. The results are presented in sections within the same chapter. And the following were the objectives which guided the study: The main objective of the study examined the Impact of Rural Urban Migration on Economic Sources in Mogadishu- Challenges and Opportunities. While the specific objectives were set:-

1) To describe social determinants of rural urban migration in Somali.

2) To identify the level of opportunities and economic sources that can be attractive factors for internal rural urban migration in Somali.

3) To assess the challenges associated with internal migration.

4) To find out solutions to the problems associated with rural-urban migration.

Generally, in this chapter, the findings of the study are compared and contrasted in regard to the literature reviewed and the implications of the study for the methodology, and the research questions which directed the study are also explored.

\section{Section A: Demographics and General information:}

Table 4.1: Gender of The Respondents

\begin{tabular}{|l|l|l|l|l|}
\hline & Frequency & Percent & Valid Percent & Cumulative Percent \\
\hline Female & 256 & 70.5 & 72.3 & 72.3 \\
Male & 98 & 27.0 & 27.7 & 100.0 \\
Total & 354 & 97.5 & 100.0 & \\
& & 2.5 & & \\
Total & & 100.0 & & \\
\hline
\end{tabular}


Based on the classification and demographics of the respondents in terms of their gender and sex, table 4.1 above indicates that $70.5 \%$ which is majority of the research respondents are Females interviewed, while $27 \%$ of the respondents are male. This further indicates that there is a very a high propensity to migrate among the different genders at any given level. According to the female members were interviewed internal rural urban migrants are most likely female headed households.

Table 4.2: Segregation of the Respondents Age

\begin{tabular}{|ll|l|l|l|l|}
\hline & Frequency & Percent & Valid Percent & Cumulative Percent \\
\hline Valid & $18-25$ & 80 & 22.5 & 22.6 & 22.6 \\
& $25--35$ & 221 & 62.1 & 62.4 & 85.0 \\
$45--45$ & 36 & 10.1 & 10.2 & 95.2 \\
55 and above & 4 & 3.7 & 3.7 & 98.9 \\
& Total & 354 & 13 & 1.1 & 100.0 \\
Total & & 109.4 & 100.0 & \\
\hline
\end{tabular}

According to the categorization of the respondents in regard to their age segregation table 4.2 , shows that $62.4 \%$ of the respondents are in between $(25-35)$, which is the majority of the rural urban migrants, followed by $22.6 \%$ and their age is in between (18-25), while $10.2 \%$ of the respondents are (35-45) years old and also $3.7 \%$ of the respondents are (45-55) and lastly followed by $1.1 \%$ of the respondents following down under55 and above. These are the minor ones according to the respondents gone through interviews and primary data collection in this research.

Looking at the $62.4 \%$ of the respondents are younger than 35 years old, this highlights internal migration in Somalia and people who are migrating from rural areas coming to Mogadishu are youth, attacked by the job opportunities and economic sources in Mogadishu, there are also insecurity issues affecting youth in rural areas to flee from the villages of origin all the way to Mogadishu by any means of transport mechanisms, alongside the droughts and recurrent shocks of the most regions in Somalia of which migration is the copping mechanism to save lives, those are the major factors contributing to the high rural urban migration of the youth. 
However the researcher identified during the data collection and focus group discussions with the respondents there are other challenges associated with internal migration and will elaborate a bit more in the research.

Table 4.3: Marital Status of the Respondents

\begin{tabular}{|ll|l|l|l|l|}
\hline & & Frequency & Percent & Valid Percent & Cumulative Percent \\
\hline Valid & Single & 55 & 15.4 & 15.5 & 15.5 \\
& Married & 244 & 68.5 & 68.9 & 84.5 \\
Divorce & 20 & 5.6 & 5.6 & 90.1 \\
& Widow & 31 & 8.7 & 8.8 & 98.9 \\
5 & 4 & 1.1 & 1.1 & 100.0 \\
& Total & 354 & 99.4 & 100.0 & \\
& & 2 & .6 & & \\
\hline
\end{tabular}

Based on the categorization of the respondents according to their marital status table 4.3, indicating that around $70 \%$ of the respondents are married and are families standing as a household, of which the greater part of the rural urban migrants are lying under, also $15 \%$ of the respondents are unmarried or single members, this is the second highest number of the respondents while $8.8 \%$ of the respondents are families whereby the husband are died, this is the third highest number of the respondents, the reason of the being pass away the husbands were not asked because of the concentration of the study on the challenges and opportunities of rural urban migration and it is subsequent effect on economic sources, that are currently available in, lastly there were $5.6 \%$ of the respondents are divorced women and struggling to survive and secure the daily breads of their children.

The researcher highlights that majority of the internal migrants coming to Mogadishu are families composing partners with their children, also looking at the UNCR report on 2012 only this year 180,000HHs (housel holds) arrived Mogadishu of which majority of the families are households standing along other family members including their children, so there should be a need for elaboration on why people are coming jointly with their family members. 
Table4.4: Level of the Education of the Respondents

\begin{tabular}{|ll|l|l|l|l|}
\hline & Frequency & Percent & Valid Percent & Cumulative Percent \\
\hline Valid & 1 & 200 & 56.3 & 56.5 & 56.5 \\
& 2 & 100 & 28.2 & 28.2 & 84.7 \\
& 8 & 8 & 2.3 & 2.3 & 87.0 \\
& 5 & 32 & 9.0 & 9.0 & 96.0 \\
& Total & 354 & 3.9 & 4.0 & 100.0 \\
& 14 & 39.7 & 100.0 & \\
\hline
\end{tabular}

The table above ( table 4.4), shows that educational level of the respondents and rate of educated migrants, as well as non-Educated throughout all the stages of the education,56.5\% of the respondents which are the internal rural urban migrants are non-educated, this is the majority of the people who is vulnerable for internal migration, they can be easily migrated because of limited educational skills and awareness which guiding them on diversifying livelihood and creating alternative sources of income before any shocks occurred. There is also a good number of the respondents $28.2 \%$ secondary level who has some basic education, also as the table shows there are people who are educated informally and did not go to school this is about $9.0 \%$ of the respondents, followed by limited rate of the respondents who are graduated from universities other have some education and this is about religious and they went to Madrasa for studying quranic schools and religious studies.

The researcher arguing that limited level of the education of rural urban migrants is the most crucial factors contributed to the increased rate of internal migration from rural to urban, because of the vulnerability of the rural people and pre-urban inhabitants, the affected people of the crises weather it is natural or human factors have limited knowledge on managing their recourses and diversifying their basics of the livelihoods before any the shocks occurred. The second point under discussion is that majority of the respondents studied Madrasa for Quranic Studies; however they did not go to school for studying and gaining other knowledge including skills and life trainings. 
Table 4.5: Does your household living in Mogadishu?

\begin{tabular}{|ll|l|l|l|l|}
\hline & & Frequency & Percent & Valid Percent & Cumulative Percent \\
\hline Valid & Yes & 300 & 81.5 & 83.1 & 83.1 \\
& No & 61 & 16.6 & 16.9 & 100.0 \\
& Total & 361 & 98.1 & 100.0 & \\
& & 7 & 1.9 & & \\
\hline
\end{tabular}

The table above indicates cataloging of the respondents according to their residential status to Mogadishu which is understudy, $83.1 \%$ of the respondents is living in Mogadishu with their households, while $16.9 \%$ of the respondents are not living in Mogadishu, but have presence and settlement in Mogadishu.

This shows that majority of rural urban migrants came with their families to live and work in Mogadishu, even thought migrating with families is questionable looking at the intensity

Table 4.6 If yes, for how long did you and your household living in Mogadishu?

\begin{tabular}{|ll|l|l|l|l|}
\hline & & & & Cumulative \\
Frequency & Percent & Valid Percent & Percent \\
\hline Valid & One up to ten Months & 100 & 27.2 & 27.6 & 27.6 \\
& 2----4 Years & 206 & 56.0 & 56.9 & 84.5 \\
& 5 Years and above & 56 & 15.2 & 15.5 & 100.0 \\
& Total & 354 & 98.4 & 100.0 & \\
& & & 1.6 & & \\
\hline
\end{tabular}


Table 4.7 indicating that $56.9 \%$ which is majority of the respondents have been in Mogadishu for the past tow up to four years, followed by the $27.6 \%$ of the respondents has been living in the capital starting from one up to ten months, while $15.5 \%$ of the respondents have been there over five years. This shows that majority of the rural urban migrants have arrived Mogadishu, during the drought of the 2011, the famine affected most of the south and central Somalia regions, so this migration was survivability and later on turned into opportunistic approach and started doing business, working and learning in Mogadishu, and also accessing opportunities in Mogadishu.

\section{Section B: Determinants and Problems associated with Rural Urban Migration}

Table 4.7 Have you ever been migrated from your place of origin?

\begin{tabular}{|ll|l|l|l|l|}
\hline & & Frequency & Percent & Valid Percent & Cumulative Percent \\
\hline Valid & Yes & 321 & 87.2 & 90.7 & 90.7 \\
& No & 33 & 9.0 & 9.3 & 100.0 \\
Total & 354 & 100.0 & 100.0 & \\
\hline
\end{tabular}

According to the table (4.7) the highest numbers of the internal rural urban migrants are people who are migrated before $90.7 \%$ of the responded were asked a question regarding to the experience of migration from rural to urban before and replied yes, demonstrating experiences of migration, while $9.3 \%$ of the respondents have no experience for internal migration in Somalia, especially migrating from rural of Somalia to Mogadishu.

Table 4.8: if Yes, Where are you Migrated from?

\begin{tabular}{|ll|l|l|l|l|}
\hline & & Frequency & Percent & Valid Percent & Cumulative Percent \\
\hline Valid & North Somalia & 40 & 11.3 & 11.3 & 11.3 \\
& South Somalia & 264 & 74.4 & 74.6 & 85.9 \\
Central Somalia & 50 & 14.1 & 14.1 & 100.0 \\
& Total & 354 & 99.7 & 100.0 & \\
Total & & 354 & 100.0 & & \\
\hline
\end{tabular}


In the table above (4.8), shows that $74.6 \%$ of the respondents migrated from southern part of Somali regions, followed by the $14.1 \%$ of the respondents are immigrates from central Somalia and $11.3 \%$ are internal rural urban migrants from northern part of Somalia.

Because of regulars and fragmented disputes were going on the southern part of Somali, the migration rates in terns rural urban migrants is very high according to other parts of Somalia, in addition to the recurrent drought in south and central Somalia especially ( Bay, Bakool, Gedo and Jubba regions), this also makes internal migration very high accordantly.

Table 4.9: What was the main reason of your migration from rural to urban?

\begin{tabular}{|c|c|c|c|c|c|}
\hline & & Frequency & Percent & Valid Percent & $\begin{array}{l}\text { Cumulative } \\
\text { Percent }\end{array}$ \\
\hline Total & $\begin{array}{l}\text { Economic Migration } \\
\text { Insecurity and inter clan } \\
\text { Conflict Migration } \\
\text { Looking for better education } \\
\text { and services } \\
\text { Total }\end{array}$ & $\begin{array}{l}150 \\
154 \\
50 \\
354 \\
354\end{array}$ & $\begin{array}{l}42.3 \\
43.4 \\
14.1 \\
99.7 \\
100.0\end{array}$ & $\begin{array}{l}42.4 \\
43.5 \\
14.1 \\
100.0\end{array}$ & $\begin{array}{l}42.4 \\
85.9 \\
100.0\end{array}$ \\
\hline
\end{tabular}

The Table above indicates $42.4 \%$ of the respondents are economics migrants, while $43.5 \%$ of the respondents are migrated from insecurity and continuous conflicts in their places, also $14.1 \%$ of the respondents are migrated looking for better education and health services in urban rather than their places.

This shows that majority of the internal migration from rural to urban, especially people who are coming to Mogadishu are migrated from the insecurity and conflicts in most parts of south and central Somalia looking a survival, second highest rates of internal migration are economic migrants and they are looking for better jobs, employments and better live generally, economic migrants can be those are migrated from the droughts and consequence of the recurrent shocks in their places of origin, especially those who arrived Mogadishu on 2011 and 2012, when the famine affected agricultural, agro-pastorals and pastoralist people, it destroyed their livelihoods and decided to migrate looking for alternative sources of livelihoods. 
Highlights is on the motive factors of internal rural urban migrants, as mentioned in the above economic motive factors, can be all the opportunities attract individuals and households to migrate and security factors, this can be choices less to decide migration or not, because it is all the looking for survivability, also looking for the better services rather than rural services, it is not always being variances between rural and urban according to the services provision, so the respondents reflecting to the objective of migration partly for better services, educations, health and limited social services which attracts the internal migration.

Table 4.10: What were the socio-economic Problems in your place of origin that forced you to migrate?

\begin{tabular}{|c|c|c|c|c|c|}
\hline & & Frequency & Percent & Valid Percent & $\begin{array}{l}\text { Cumulative } \\
\text { Percent }\end{array}$ \\
\hline \multirow[t]{4}{*}{ Valid } & $\begin{array}{l}\text { Lack of employment } \\
\text { Opportunities }\end{array}$ & 100 & 28.2 & 28.2 & 28.2 \\
\hline & Droughts and Natural Shocks & 204 & 57.5 & 57.6 & 85.9 \\
\hline & Others & 50 & 14.1 & 14.1 & 100.0 \\
\hline & Total & 354 & 99.7 & 100.0 & \\
\hline Total & & 354 & 100.0 & & \\
\hline
\end{tabular}

According to table above (4.10) indicating that socio economic problems which is causing specifically rural urban migration, $57.5 \%$ of the respondents are migrated from the droughts in their places of origin as well as the natural shocks (Floods and droughts), also $28.2 \%$ of the respondents are suffered from lack of employment opportunities which make them migrate and look for the better opportunities of getting jobs and cover their lives.

Although migration of people and livestock is not unusual during the dry season, this appears to be the first time ever pastoralists and their livestock have migrated into the cities, a situation that portrays the severity of the drought situation in the country increased on the droughts of 2011, it was partly copying strategy on surviving human and livestock live. According to the experience of researcher in the famine of the 2011, there were even pastoralists arriving to Mogadishu, and because of limited pasture the pastoralist were even buying the known trees in the urban especially Mogadishu to feed their animals ( Cattle and Camels) as a fodder. 
4.11: Do you agree on, Apart from economic reason there are other pushing factors encouraging on rural urban migration?

\begin{tabular}{|ll|l|l|l|l|}
\hline & Frequency & Percent & Valid Percent & Cumulative Percent \\
\hline Valid & Yes & 280 & 78.9 & 79.1 & 79.1 \\
& & & 6.8 & 21.1 & 85.9 \\
& Total & 354 & 99.7 & 100.0 & 100.0 \\
\hline & & 354 & 100.0 & & \\
\hline
\end{tabular}

Table (4.11) indicating that, $79.1 \%$ of the respondents revealed that other factors than economic migration are causing rural internal migration and antenatal migration, while also $21.1 \%$ of the respondent revealed that rural urban migration is not caused by other factors, indicating that economic reasons are the only factors causing for migration from the rural (the place of origin) to urban specifically Mogadishu, which is under study.

The study data has been collected from the specific target population, which is rural urban migration or in other words internal migration, the respondents were asked about Apart from economic reason there are other pushing factors encouraging on rural urban migration, if there is other factors pushing internal immigrants to migrate to Mogadishu.

Of course this should be highlighted as many researchers demonstrating, the migration in Somalia is not only for economic purposes, the security challenging situations in south and central Somalia can be vital role encouraging internal displacements and migrations form one place to another as the researcher demonstrated in the above in relation to the other questions. This is because of opposing politics and conflicts in Somalia. Also droughts, floods and other natural disasters are also contributing and plying vital role again for increments of the internal migration from rural to urban. 


\subsection{2: Which gender is more likely to migrate on completion at any given level?}

\begin{tabular}{|ll|l|l|l|l|}
\hline & Frequency & Percent & Valid Percent & $\begin{array}{l}\text { Cumulative } \\
\text { Percent }\end{array}$ \\
\hline Valid & Female & 157 & 44.2 & 44.4 & 44.4 \\
& Male & 30 & 8.5 & 8.5 & 52.8 \\
& $\begin{array}{l}\text { c)Both Male and Female have } \\
\text { high intensity of rural urban } \\
\text { migration }\end{array}$ & 167 & 47.0 & 47.2 & \\
\\
Total
\end{tabular}

According to the classification of the respondents looking at which gender is more like to migrate both male and female the researcher found that both male and female are likely to migrate in percentage of $47.2 \%$ of the responders, while females migrated in a rate of $44 \%$ of the respondents answer's, followed by the $8.5 \%$ of the male are migrated in views of the some respondents.

Migration is a common phenomenon among the people in the world, particularly Somali people who have nomadic culture of migration and most of them are pastoralist, following behind the pasture and water for the better of their livestock.

Again Somalia people are effected especially the people under the study in south and central Somalia, so whenever and wherever the pushing factors of migration is available people are exposed to migrate regardless gender (male and female), age (young and elder), it is considerable sometimes and some specific hazards affect for some groups or members of the society, such conflicts and targeting for specific people, such whealth individuals and some other hazards that might affect only youths, such insecurity and security challenges in Somalia, targeting youth in relation to the suspicions. 
4. 13: What is the level of opportunities and economic sources that can be attractive factors for internal rural urban migration in Somali- Mogadishu?

\begin{tabular}{|c|c|c|c|c|c|}
\hline & & Frequency & Percent & Valid Percent & Cumulative Percent \\
\hline \multirow[t]{4}{*}{ Valid } & High & 101 & 28.4 & 28.5 & 28.5 \\
\hline & Medium & 206 & 57.9 & 58.2 & 86.7 \\
\hline & Low & 47 & 13.2 & 13.3 & 100.0 \\
\hline & Total & 354 & 99.4 & 100.0 & \\
\hline Total & & 354 & 100.0 & & \\
\hline
\end{tabular}

Table 4.13 revealed that $66.4 \%$ of the respondents, rural urban migration are the copying strategy to cope with the recurrent droughts and floods in south and central Somali regions, while $26.8 \%$ of the respondents are also revealing that rural urban migration is not copying strategies, but it is a normal phenomenon of the people's movement from one location to another due to the cause from the environmental and human reflection, followed by the last rate of the internal migration around $6.8 \%$ of the respondents reveals, no ideas of whether rural urban migration is a copying strategy or a natural phenomena exercised by the people.

The highlight is that majority of the people who were interviewed, including recent migration are reveling this is a copying strategy and it will continue across the urban cities, while and whenever the disasters are taking place, this is supported by the researcher's argument on migration strategies and the effect of the urbanization, as well as the growth of the cities attacking, people to urbanize themselves, and place for the families. Other This is also supported in the literature review only one year 2011, the UNCR Report (2011), reflected that Mogadishu 180,000HHs, this people arrived to Mogadishu to survive and look for the better place to live, of course this was not their choice, but they were forced to flee from the home and settle into Mogadishu. 
4.14: Do you agree rural urban migration is a copying strategy of recurrent shocks (droughts, Floods and Conflicts) in some south Somali regions

\begin{tabular}{|c|c|c|c|c|c|}
\hline & & Frequency & Percent & Valid Percent & Cumulative Percent \\
\hline \multirow[t]{4}{*}{ Valid } & Agree & 235 & 66.0 & 66.4 & 66.4 \\
\hline & Disagree & 95 & 26.7 & 26.8 & 93.2 \\
\hline & Neutral & 24 & 6.7 & 6.8 & 100.0 \\
\hline & Total & 354 & 99.4 & 100.0 & \\
\hline Total & & 354 & 100.0 & & \\
\hline
\end{tabular}

According to the opportunities and economic sources, that can be attractive factors and subsequent encouraging internal rural urban migrants in regard to Mogadishu, in the table (4.14), demonstrating that 28.5\% of the respondents agreed that economic opportunities in Mogadishu are very high, that is why many people are migrated from the regions and coming to Mogadishu, also 58.2\% of the respondents revealed that opportunities in Mogadishu is medium, but there still potentiality of being Mogadishu a green side, attracting internal migrants, finally small number of the respondents $13.3 \%$ believes that opportunities in Mogadishu is low, so according to them, no need for left from home and migrate to Mogadishu.

\section{Section C: Opportunities and Economic Sources of rural urban Migration}

\subsection{5: Are you now working in Mogadishu?}

\begin{tabular}{|ll|l|l|l|l|}
\hline & & Frequency & Percent & Valid Percent & Cumulative Percent \\
\hline Valid & Yes & 263 & 73.9 & 74.3 & 74.3 \\
& 3 & 91 & 25.6 & 25.7 & 100.0 \\
& Total & 354 & 99.4 & 100.0 & \\
\hline
\end{tabular}


Looking at the employment opportunities in table (4.15) currently $74.3 \%$ of the respondents are working in Mogadishu, while 25.7\% of the respondents are not working and they are unemployed formally or informally.

\subsection{6: If yes, what type of your employment/ Job?}

\begin{tabular}{|ll|l|l|l|l|}
\hline & Frequency & Percent & Valid Percent & Percent \\
\hline Valid & Casual Labor & 244 & 68.5 & 68.9 & 68.9 \\
& Business person & 68 & 19.1 & 19.2 & 88.1 \\
& Teacher/ Lecturer & 23 & 6.5 & 6.5 & 94.6 \\
Others, & 19 & 5.3 & 5.4 & 100.0 \\
& Total & 354 & 99.4 & 100.0 & \\
\hline
\end{tabular}

In the table (4.16), this is linked to the employment opportunities in table (4.15), respondents were asked on the type of the employments and what they are doing, majority of the rural urban migrants are workers and doing casual work in Mogadishu, around 68.9\% and approximately $19.2 \%$ of the respondents are business persons and involved in this sector, while also a limited percentage of the respondents $6.5 \%$ are involved in the education field and employed as teachers and lecturers with in education, this means that majority of the rural urban migrants are casual labour and even sometimes innovate new business ideas, that has not been explored before by the local residents of Mogadishu.

As researcher highlights the biggest market in Somali Bakaaro, many people are employed in this market and mainly are casual labors from the internal migrants (rural urban migrants), this people are porters using, wooden wheelbarrows, donkey and donkey carts and also local motor cycles, in some cases the rural urban migrants interact with people and start small scale business and eventually resettle the city buying new houses and educating their children. Also it is visible a gain in some cases the interaction of the rural urban migrants in Mogadishu and get involved in a brokers and other services that might need for some people who need identification and recognition of the local people 
According to the classification of the respondents in terms of their work in the place of origin, table (4.17) indicating that $48.9 \%$ of the respondents were farmers before they migrate to Mogadishu and $20.6 \%$ of the respondents were pastoralist, while $18.6 \%$ of the respondents were also trade/small business, followed by the $11.9 \%$ of the respondents were doing casual labors when were they in the place of origin, this shows that because of the effects of the droughts farmers and pastoralist are the most effected groups and now are involved, some casual labors and business as mentioned above.

\subsection{7: What were you working on when in your place of origin or before migrating to Mogadishu}

\begin{tabular}{|ll|l|l|l|l|}
\hline & Frequency & Percent & Valid Percent & $\begin{array}{l}\text { Pumulative } \\
\text { Percent }\end{array}$ \\
\hline Valid & Farmers & 173 & 48.6 & 48.9 & 48.9 \\
& Pastoralist & 73 & 20.5 & 20.6 & 69.5 \\
Trade/ Small business & 66 & 18.5 & 18.6 & 88.1 \\
Casual labor & 42 & 11.8 & 11.9 & 100.0 \\
Total & 354 & 99.4 & 100.0 & \\
\hline
\end{tabular}

4.18: When you have come to Mogadishu would you met your expectation?

\begin{tabular}{|ll|l|l|l|l|}
\hline & Frequency & Percent & Valid Percent & Cumulative Percent \\
\hline Valid & Yes & 230 & 64.2 & 64.2 & 64.2 \\
& No & 128 & 35.8 & 35.8 & 100.0 \\
& Total & 354 & 100.0 & 100.0 & \\
\hline
\end{tabular}

Table above (4.18), shows that respondents reflect their ideas on how they got about migrating from rural to urban and if they met their expectations, $64.2 \%$ of the respondents agreed that they have met their expectation on coming to Mogadishu, while 35.8\% of the respondents are reflecting that journey to Mogadishu was not successful and have not realized their objectives of migrating to Mogadishu. 
4.19: What is the impact of rural urban migration on mobilizing local economic sources and opportunities in Mogadishu

\begin{tabular}{|c|c|c|c|c|c|}
\hline & & Frequency & Percent & Valid Percent & Cumulative Percent \\
\hline \multirow[t]{4}{*}{ Valid } & Positive Impact & 130 & 36.3 & 36.4 & 36.4 \\
\hline & Negative Impact & 184 & 51.4 & 51.5 & 88.0 \\
\hline & No Impact & 43 & 12.0 & 12.0 & 100.0 \\
\hline & Total & 354 & 99.7 & 100.0 & \\
\hline Total & & 354 & 100.0 & & \\
\hline
\end{tabular}

Table (4.19) indicates that rural urban migration has a positive impact on mobilizing local economic sources and opportunities in Somalia, around $36.4 \%$ of the respondents revealed a positive impact, followed by the $51.5 \%$ of the respondents reflecting to the negative impact of the rural urban migration and $12 \%$ of the respondents are also reflecting no impact of the internal rural urban migration.

The internal migration of the rural urban increased in recent days, because of the recurrent and environmental changes affected droughts and floods, which turned into negative consequence on the migrated people, to the different parts of Somalia, specifically Mogadishu hosted the major part of the migration influxes.

Section D: Challenges associated with internal migration

4.20: Can you mention some challenges which you faced during and after your migration?

\begin{tabular}{|l|l|l|l|l|}
\hline & Frequency & Percent & Valid Percent & Commutative \\
\hline Security & 110 & 30.7 & 31.1 & 31 \\
Lack of & 86 & 24.0 & 24.3 & 55.4 \\
transportation & & & & \\
Home sick & 101 & 28.2 & 28.5 & 83.9 \\
Adaptation with & 57 & 15.9 & 16.1 & 100 \\
Urban & & & & \\
Total & 354 & 98.9 & 100.0 & \\
\hline
\end{tabular}


Looking at the challenges associated with internal migration, in table (4.20), respondents reflecting there were some challenges alongside the migration from rural to urban, where $31.1 \%$ of the respondents had security challenges traveling to Mogadishu, also $24.3 \%$ of respondents had transportation challenges, followed the $28.5 \%$ of the responders were unable to leave from their home, because of their emotionality and love of the home land where they were born, others had challenges on the adaptation of the environment, especially where they migrated to, in terms some cultural barriers and living standard of the urban areas.

The challenges of the migration, both internal migration (rural urban migration from one specific local city to another city) or external migration (migrating to outside the country), always had challenges and this can be only a full study looking at the dimension of social cultural problems of the migration, however there are also some challenges associated with internal migration including transportation, limited knowledge on urban areas, that will reflect to the adaptation of the people to the migrated land.

\subsection{1: Do you think that rural urban migration impact on interdependence of rural products to urban production and consumption?}

\begin{tabular}{|ll|l|l|l|l|}
\hline & & Frequency & Percent & Valid Percent & Cumulative Percent \\
\hline Valid & Yes & 269 & 75.1 & 76.0 & 76.0 \\
& No & 85 & 23.7 & 24.0 & 100.0 \\
& Total & 354 & 98.9 & 100.0 & \\
Total & & 354 & 100.0 & & \\
\hline
\end{tabular}

In table (4.21) the respondents reflecting that rural urban migration has a consequence on the production of the rural, which is lightly, will reduce the local economy around $76 \%$ of the respondents revealed yes, while $24 \%$ of the respondents are reflecting that there are no relation between the interdependence of the rural production and the economics of the urban cities.

The researcher reflecting that there are relations of the rural production and local economic growth, the rural products, whether it is livestock products and agricultural products are transported to the large urban cities for business purposes and this will strength to the local economic relations and country's economic growth. 
Alongside the challenges of the internal migration of Somalia, respondents were presented to an interview where semi-structured interview has been guided to the discussion. The discussions were concerning on the last objective of the study, solutions of the problems associated with the internal migration, especially rural urban migration in Somalia.

The researcher will summarize the discussion points, looking at the economic migrants and security related migrants as well as the impact of internal migration on economic sources in Mogadishu.

For the economic migrants, the solution is creating alternative livelihood sources in their places of origin, this can be supporting Farmers on agricultural sector equipments and financing them to improve agricultural production, which also has it is own impact on the growth of local economic scales, livestock investment and provision of treatments to the pastoralists, this will engage keeping the pastoralist in the rural and not to migrated as well as the resilience for droughts and recurrent shock affecting the live of the human and livestock.

In addition to the giving the rural people some skills and knowledge on early warning systems that might help on preparing for dry seasons, so that they will have resistance when the droughts accrued, all the above mentioned are the solutions for the economic migrants of the internal migration in Somalia.

According to the security related migration, the respondents and the researcher considers the biggest challenges of the Somalia as country and as a people, this could be solved only negotiations and reconciliation of the conflicted parts within Somalia overly and specifically the areas where people are usually migrated from because of in security south and central Somalia is an example, "the security challenges are over the capacity of the internal migrants and sometimes over the Somali people they are many actors involving in Somali politics" aid by the Bishar Abdi a rural urban migrants living in Dharkeynley district.

The rural urban migrants have an impact on the economic sources of Mogadishu; they explore new business and economic sources in Bakaaro Market the biggest market in Somalia, they are mainly employed as casual labors providing support services to the business activities in the market, while they are starting business from small scale size to the medium ones and for the time being some rural urban migrants are educated and employed in the education sector both teaching and lecturing in education institutions in Mogadishu. 


\section{CHAPTER FIVE \\ SUMMARY OF FINDINGS, CONCLUTIONS AND RECOMMENDATIONS}

\section{1: Introduction}

In this chapter, the researcher described about summary of the study, conclusions of the research findings according to the primary and secondary data of the research and finally the researcher rolled out the study presenting recommendations and areas that might need to go for father studies in the future.

\section{2: Summary}

This study is intended to investigate the impact of rural urban migration on economic sources in Mogadishu- challenges and opportunities, despite inadequate employment opportunities and lack of effective employment agencies that can be equally treated to the job seekers, the study will look at how the rural-urban migrants mobilize economic sources to sustain and adapt the life in Mogadishu. Rural-urban migration has also created social problems on rural based production and reduced the integration and economic interdependence of the rural urban cycle as depicted on population density in Mogadishu.

So, this study analyzed the major push factors for rural-urban migration in Somalia; problems associated with internal migration and solutions of the problems associated with rural urban migrants, why Mogadishu is an attractive city for internal migrants. How do rural migrants to urban Mogadishu create and mobilize new economic opportunities that had not been seen by those who were there so many years and converting these new opportunities into sustainable income sources to the migrants. Not only the positive aspects but also the density of the population especially the new ones and how the hosted communities interact with people who had come to Mogadishu earlier.

This study contributed to describe on the impact of rural urban migration on economic sources in Mogadishu- challenges and opportunities.

The study has set out an objectives and research questions that have required findings to be achieved during the course of the research period.

Described social determinants of rural urban migration in Somali Identified the level of opportunities and economic sources that can be attractive factors for internal rural urban migration in Somali Assessed the challenges associated with internal migration Find out solutions to the problems associated with rural-urban migration. 


\section{3: Conclusion of the Findings.}

The research covered on impact of rural urban migration on economic sources in Mogadishu, looking at the associated challenges and opportunities with the internal migration and internal immigrants.

The researcher found that majority of the internal migration from rural to urban, especially people who are coming to Mogadishu are migrated from the insecurity and conflicts in most parts of south and central Somalia looking for survival, second highest rates of internal migration are economic migrants and they are looking for better jobs, employments and better live standard generally, economic migrants can be those who are migrated from the droughts and consequence of the recurrent shocks in their places of origin, especially those who arrived to Mogadishu on 2011 and 2012, when the famine affected agricultural, agropastorals and pastoralist people and had destroyed their livelihoods, they decided to migrate looking for alternative sources of livelihoods.

The motivation factors of the internal rural urban migrants, as mentioned in the above economic motive factors, can be all the opportunities attract individuals and households to migrate and followed by the security factors, this can be choices less to decide migration or not, because it is all about looking for survivability, also looking for the better services rather than rural services, it is not always being variances between rural and urban according to the services provision, so the respondents reflecting to the objective of migration partly for better services, educations, health and limited social services which attracts the internal migration.

According to the economic opportunities in Mogadishu, the researcher highlighted the biggest market in Somali Bakaaro, many people are employed in this market and mainly are casual labors from the internal migrants (rural urban migrants), this people are porters using wooden wheelbarrows, donkey and donkey carts and also local motor cycles, a limited number of them are employed in the education sectors teaching in the private schools and lecturing in the universities, in some cases the rural urban migrants interact with people and start small scale business and eventually resettle the city buying new houses and educating their children.

\section{4: General Recommendations}

There is always a mutual relationship between rural productions and urban economic, this is just like cycle same to the cycle of the living things on the earth; each one will contribute the general status of the country's economic and well being of the people in the country. The rural products contribute to the national income, while the urban services contributing to the well being of the local economic developments, internal 
migration from rural to urban affect the balance and equilibrium of the country's economy. The following are the recommendations contributing to reduce the internal rural urban migrants.

Government has to encourage the local production, especially consideration to agricultural sector, livestock and fishing as Somali has one of the longest coasts in Africa, the researcher heighted that some people are migrating from part of south regions, where the biggest rivers in Somali are passing; this is because of limited support to the farmers and pastoralists.

An infrastructure including schools, public hospitals and transport roads has to bring back at local level from tow to villages; this will help improve of social service deliveries and will reduce the internal migration.

Creating alternative sources of income and improving the employment opportunities to skilled and non skilled individuals and diversifying of the human livelihood sources in the rural and pre-urban areas to mitigate the internal migration from rural to urban and will maintain balancing between rural and urban.

\section{5: Areas for further research}

Based on the findings of the study, the researcher recommended that a similar study should be done on another organization the similar line of business in order to access whether the same results will be attained. 


\section{REFERENCES}

[1]. De Haan and Rogally, R. (1994) Non-farm income and inequality in rural Pakistan, Journal of Development Studies, 31, 1, 110-33

[2]. Lanzona, 1998, Agesa, 2001 Migration and the urban to rural earnings difference: a sample selection approach, Journal of Development Studies, 49, 4, 847-65.

[3]. Michael J. Greenwood Gubert (2002) Those in Kayes The impact of remittances on their recipients in Africa, DIAL Working Paper DT-2002-1.

[4]. UN Habitat (Report 2008). Natural Resources Development Council 1957 Planning Survey of the Southern Transvaal: the Pretoria-Witwatersrand Vereeniging Area, Pretoria

[5]. UN FAO (2008). Pillay U 2006 SA’s global city region of the future, in Business Day 11 July 2006

[6]. Harper (November 2001) Barham B. and S. Boucher (1998) Migration, remittances and inequality: estimating the

[7]. Net effect of migration on income distribution, Journal of Development Economics, 55, 307-31.

[8]. Eshetu Gurmu (2012) on the specification and estimation of macro rural urban migration functions: With an application to Indian data, Oxford Bulletin of Economics and Statistics, 43, 7-29.

[9]. Rudzitis (1989 and N. Naqvi (1988) Urban unemployment and non-immiserizing growth Journal of Development Economics, 28, 365-7.

[10]. Gundars ( 1990) Mabin A 1995 Conceptualizing, making and governing the Witwatersrand, paper presented to Africa's urban past conference, School of Oriental and African Studies, University of London.

[11]. Akindelly, (Nove, 2009). Mabin A and R Hunter 1993 Review of conditions and trends affecting development in the Pretoria- Witwatersrand-Vereeniging (PWV) region.

[12]. Mabin A and R Hunter 1993 Review of conditions and trends affecting development in the PretoriaWitwatersrand-Vereeniging (PWV) region.

[13]. Harris and Todaro (1970) Garrison H. (1982) Internal migration in Mexico: A test of the Todaro model, Food Research Institute Studies, 18, 197-214.

[14]. Webster's New World Dictionary English, Property of United States of America 


\section{WORK PLAN}

This is the estimated time plan of the study. It is essential in that it enables the researcher to assess the feasibility of conducting the research within the scheduled time frame. It will also enable the researcher to stay on schedule as the research progresses.

\begin{tabular}{|l|l|}
\hline PERIOD & TASK \\
\hline $15^{\text {th }}-31^{\text {st }}$ April 2014 & Vetting of the research topic \\
\hline $1^{\text {st }}$ to $31^{\text {st }}$ May 2014 & Proposal writing \\
\hline $1^{\text {st }}$ to $20^{\text {th }}$ June 2014 & $\begin{array}{l}\text { Proposal vetting, discussing with the advisor and } \\
\text { making corrections }\end{array}$ \\
\hline $11^{\text {th }}$ to $21^{\text {st }}$ July 2014 & $\begin{array}{l}\text { Develop and validate research tools, submit the } \\
\text { proposal to the supervisor. }\end{array}$ \\
\hline 22 July -10 August, 2014 & $\begin{array}{l}\text { Corrections of Supervisor's Comments on the } \\
\text { Research Proposal. }\end{array}$ \\
\hline $14^{\text {th }}$ August-20 August, 2014 & $\begin{array}{l}\text { Submission of the second Draft of the Research } \\
\text { Proposal after Correction. }\end{array}$ \\
\hline 20 August----10 September, 2014 & \begin{tabular}{l} 
Submission of the Final Draft of the paper \\
\hline
\end{tabular} \\
\hline
\end{tabular}

\section{Budget estimates}

\begin{tabular}{|l|l|l|l|}
\hline Item & Quantity & Amount(USD) & Total(USD) \\
\hline Ream of papers & 8 & 5 & 40 \\
\hline Typing and printing & 3 Copies & 25 & 75 \\
\hline Transport & 5 trips & 20 & 100 \\
\hline Binding and & 5 copies & 5 & 25 \\
\hline $\begin{array}{l}\text { Accommodation } \\
\text { meals }\end{array}$ & & 20 & 400 \\
\hline $\begin{array}{l}\text { Contingencies } \\
\text { Internet \& phone charges }\end{array}$ & 1 & 100 & 120 \\
\hline Total & 80 & & 80 \\
\hline
\end{tabular}




\section{Appendix: 1}

\section{Questionnaire}

\section{Researcher's Introductory Message.}

Dear Respondent,

I am conducting a research as one of the requirements for the award of a Masters degree in Development Studies from Kampala University.

This questionnaire is designed to investigate the 'Impact of Rural Urban Migration on Economic Sources in Mogadishu - Challenges and opportunities. The research is partial fulfillment of my Master's Degree in Development Studies credited by Kampla University- Graduate School.

The information you supplied/provided will only be used for academic purpose and we guarantee that your answers will be strictly treated confidential.

Thank you in advance for taking time to fill this questionnaire voluntarily

\section{Researcher:}

Name: $\quad$ Hassan Hussein Ibrahim

University: Kampala

Degree: Master

Field: $\quad$ Development Studies

\section{Section A: Demographic information}

\section{Gender:}

Male ( ) Female ( )

2. Age:

$18-25(\quad$ ) 25---35 ( ) 35---45 ( ) 45---55 ( ) above 55 ( ) 


\section{Marital Status}

What is Your Current Marital Status?

Single ( ) Married ( ) Divorced ( ) Widow ( )

\section{Level of Education:}

Secondary ( ) University ( ) above university ( ) Informal education ( )

\section{Residential Status of the respondent}

Does your household living in Mogadishu?

Yes ( ) No ( )

6. If yes, for how long do you and your household living in Mogadishu?

One up to ten Months ( ) - 2----4 Years ( ） 5 Years and above ( )

\section{Section B: Determinants and Problems associated with Rural Urban Migration.}

7. Have you ever been migrated from your place of origin?

Yes ( ) No ( )

8. If yes, where are you migrated from?

North Somalia

South Somalia

Central Somalia

9. What was the main reason of your migration from rural to urban?

Economic Migration

Insecurity and inter clan Conflict Migration ( )

Looking for better education and services ( )

Others. Please Specify-

10. What were the socio-economic Problems in your place of origin that forced you to migrate?

Lack of employment Opportunities

Droughts and Natural Shocks

Others

11. Do you agree on, Apart from economic reason there are other pushing factors encouraging on rural urban migration?

- Yes, ( ) No( )

12. If Yes, Please Specify-

13. Which gender is more likely to migrate on completion at any given level?

a) Male

b) Female 
c) Both Male and Female have high intensity of rural urban migration

14. Do you agree rural urban migration is a copying strategy of recurrent shocks (droughts, Floods and Conflicts) in some south Somali regions?
Agree (
- Disagree ( )
- Neutral ( ）

\section{Section C: Opportunities and Economic Sources of rural urban Migration.}

15. What is the level of opportunities and economic sources that can be attractive factors for internal rural urban migration in Somali- Mogadishu?
High
) Medium (
) $\operatorname{Low}(\quad)$

16. Are you now working in Mogadishu?

Yes ( ) No ( )

17. If yes, what type of your employment/ Job?

Casual Labor ( )

Business person ( )

Teacher/ Lecturer ( $\quad$ )

Others,

18. What were you working on when in your place of origin or before migrating to Mogadishu?

Farmers

Pastoralist

Trade/ Small business ( $\quad$ )

Casual labor

Other, Please Specify

19. In your opinion do you think there are economic opportunities that can be found only by the Rural Urban immigrants rather than previous residents?

Yes, $(\quad)$ No $\quad(\quad)$

20. When you have come to Mogadishu would you met your expectation?

Yes $(\quad)$ No $($ )

21. If yes, Please mention and List the opportunities: 
22. What is the level of opportunities and economic sources that can be attractive factors for internal rural urban migration in Somali?
High
) Medium (
) $\operatorname{Low}(\quad)$

23. What is the impact of rural urban migration on mobilizing local economic sources and opportunities in Mogadishu?

- Positive Impact $(\quad ）$ - Negative Impact $(\quad ）$ No Impact （ ）

\section{Section D: Challenges associated with internal Migration.}

24. Can you mention some challenges which you faced during and after your migration?

25. Do you think that rural urban migration impact on interdependence of rural products to urban production and consumption?

Yes ( ) No ( )

\section{Appendix 2 Interview Guide}

\section{Researcher's Introductory Message.}

Dear Respondent,

I am conducting a research as one of the requirements for the award of a Masters degree in Development Studies from Kampala University.

This interview is designed to investigate the 'Impact of Rural Urban Migration on Economic Sources in Mogadishu - Challenges and opportunities. The research is partial fulfillment of my Master's Degree in Development Studies credited by Kampla University- Graduate School.

The information you supplied/provided will only be used for academic purpose and we guarantee that your answers will be strictly treated confidential.

Thank you in advance for taking time to fill this questionnaire voluntarily

\section{Date of Interview:}

\section{Qualification of the Respondent (Please Tick where Applicable)}

a. Secondary

b. Diploma, 

c. University Degree,
d. Others, Specify

\section{Marital Status}
a. Single
b. $\quad$ Married
c. Windowed
d. Divorced

Gender (Please Tick One) 1) Male:

2) Female:

\section{Age Categories:}

$18-25(\quad) \quad 25---35(\quad) 35---45(\quad) \quad 45----55(\quad) \quad 55$ and Above ( )

What are the economic opportunities of rural urban migration?

What impact does rural urban migration caused on economic sources of

Mogadishu?

- Positives Impact ( ) Negative Impact ( )

If Positive or negative explained your arguments?

What are the major challenges of migrating from rural to urban?

What are the alternative measures to be taken to mitigate the problems associated with internal migration? 